\title{
Developing Ergonomic Balls
}

\author{
Eka Nugraha*, Ricky Wibowo, Burhan Hambali \\ Physical Education Department, Faculty of Sport and Health Education \\ Universitas Pendidikan Indonesia \\ Bandung, Indonesia \\ *ekafok@upi.edu
}

\begin{abstract}
Modified sports equipment is such an important factor in having learning media in physical education. This study aimed to design a physical education learning medium with ergonomic in accordance with the anthropometric mapping of Indonesian students. This study used a mixed method with design basic research (DBR) employing various instruments to collect data including document study, survey, interview, and direct observation. The population in this study was all junior high school students all over Indonesia and 1018 out of them were selected to be the sample. Based on the data analysis, it is found that $95 \%$ of physical education teachers used formal sports equipment without considering the anthropometric aspects of their students. Thus, it is concluded that it is necessary to create a learning medium with good ergonomic in accordance with the anthropometric mapping of students and in line with the development of literature in physical education.
\end{abstract}

Keywords—physical education learning media; ergonomic balls; modified sports equipment

\section{INTRODUCTION}

Learning media is an inseparable factor in the success of teaching and learning, including in physical education. In physical education, modified equipment of such sport as volleyball, basketball, and other types gives more chances of skill improvement [1-3] and other various equipment and facilities in accordance with improvement of effective teaching and learning of physical education [4]. However, the fact shows that most physical education teachers do not understand this so that they use the real equipment used in sport without any modification based on the needs of learning outcome. In the industry, this type of modification is called ergonomic.

According to Stockbridge, ergonomy related to humans are knowledge on bodies; their abilities, limitations, and characteristics relevant with a certain design [5]. Moreover, Santosa $G$ points out that ergonomic is about adjusting the anatomic and physiological conditions of children for the sake of their safety [6]. In the context of pediatric ergonomics, it has to be clearly understood that children are not the miniature of adults. Thus, there needs to be learning media relevant to the development of children's growth, either physical or psychological growth [7,8]. In physical education, some students are reluctant to actively participate since they fear or do not have confidence to play using the real equipment of a certain sport, a standardized ball for instance. In fact, the ball is not relevant to the anthropometric aspects of students.
As a matter of fact, learning is a process of behavioral changing. Some of the indicators of learning are 1) learning is influenced by training and experiences; 2) learning processes cannot be directly evaluated; however, the results are reflected from skill improvement; and 3) individual change of skills are permanent [9]. In learning, media are an important component significantly influencing learning outcomes. There are four main components of lesson planning including aims, content, method, and assessment/ evaluation as shown in Figure 1 [10].

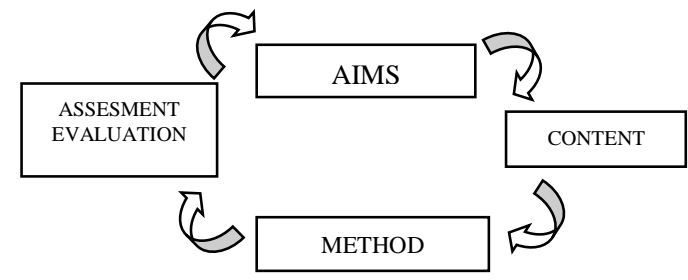

Fig. 1. Cycle of lesson planning [10].

Since learning media are a supporting aid of learning, the implementation should be carefully planned by teachers. Selection of media should consider the following criteria 1) learning objectives; 2) theoretical framework; 3) students' characteristics; 4) students' learning styles; and 5) facilities available [11]. This idea is also supported by another study stating that the selection and the use of equipment in learning are an important aspect in a well-organized lesson [12].

In physical education, the equipment is divided into small and large equipment. Small equipment is such things as balls, batting tee, cones, etc. [13]. Several studies related to the use of equipment of learning media in teaching and learning processes have been conducted. A study by Nugraha and Hasanah proved that there is a significant influence of modified equipment towards learning outcomes in elementary schools [14]. Moreover, a study by Wijoyo revealed that the use of a modified ball is more effective compared to the use of a formal ball [14]. A study by Rasip finds out that the modified balls are effective to use in learning [15]. In short, the use of modified balls offered the students more fun so that they were getting more enthusiastic in the teaching and learning process. In addition, the use of modified balls also gave more opportunities for students to develop their cognitive, affective, and psychomotoric domains. Figure 2 shows an example of a modified basketball made out of petroleum waste (PU $=$ Polu Urethane) based on a natural rubber $($ NBR $=$ Nylo Butan Rubber) or fruit waste, or a combination of all. This type of 
ball is produced in overseas countries such as China, the Netherlands, USA, etc.

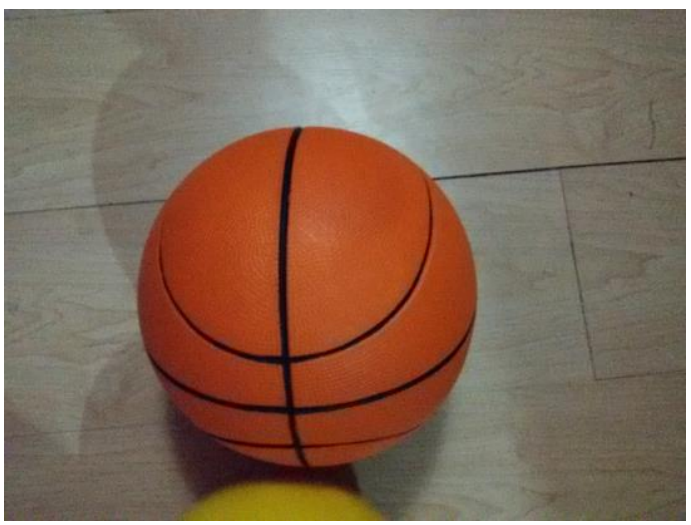

Fig. 2. A modified basketball.

Based on the aforementioned reasons, this study aimed to design physical education learning media in a form of modified balls, test the ball in a laboratory, and test their use in selected junior high schools.

\section{RESEARCH METHOD}

The method used in this study was a mixed method using design bases research [16] consisting of repetitive design, development, and revision $[17,18]$ as shown by Figure 3 .

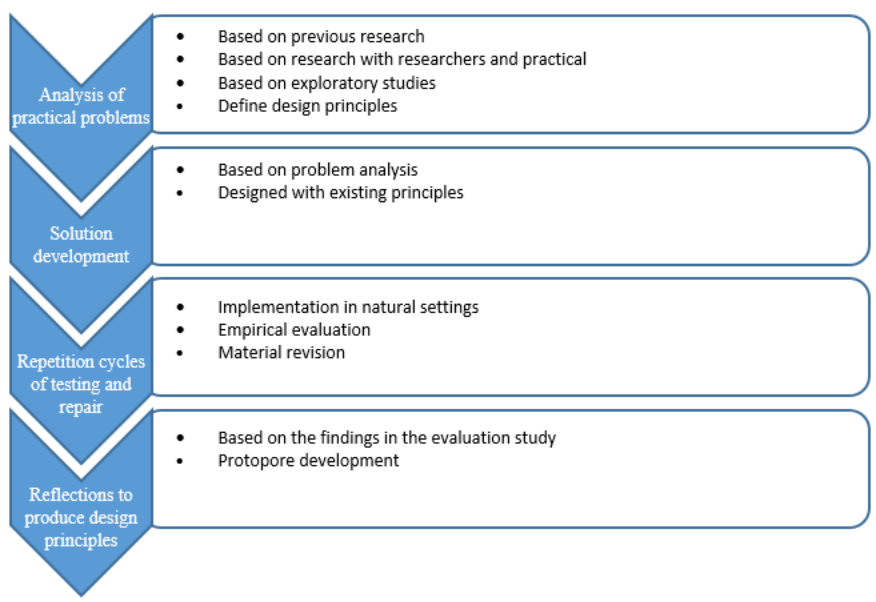

Fig. 3. Design of basic research by Reeves [17].

\section{RESULTS AND DISCUSSION}

Based on the interview with physical education teachers, it has been found that $95 \%$ of the teachers in West Java used a formal sport equipment for learning. Thus, it is strongly recommended that schools start considering the ergonomic aspects of the equipment used in their physical education [19] to promote learning with constructivism approach by Piaget [20]. It is believed that planning learning media should be planned futuristically [21].

Based on the studied literature and anthropometric mapping of seventh graders in Indonesia, an ergonomic ball is designed as explained in Table 1.
TABLE I. DESIGNING AN ERGONOMIC BALL

\begin{tabular}{|c|c|c|c|}
\hline Type of Test & Unit & Requirement & Remark \\
\hline $\begin{array}{l}\text { The ball condition } \\
\text { The ball is still } \\
\text { round after bouncing } \\
\text { The ball surface } \\
\text { follow the students } \\
\text { hands' contoure }\end{array}$ & - & $\begin{array}{l}\text { The ball surface } \\
\text { is not sticky and } \\
\text { there is no } \\
\text { printing waste. } \\
\text { The ball surface } \\
\text { is coated with } \\
\text { two layers with } \\
\text { high density yet } \\
\text { not stiff. }\end{array}$ & $\begin{array}{l}\text { The ball surface is } \\
\text { not sticky and } \\
\text { sliperry and is back } \\
\text { immediately to the } \\
\text { previous state after } \\
\text { modification. }\end{array}$ \\
\hline $\begin{array}{l}\text { Surface area of the } \\
\text { ball }\end{array}$ & $\mathrm{cm}$ & $\begin{array}{l}68.00-73.00 \\
\leq 1.5\end{array}$ & $\begin{array}{l}\text { The surface area of } \\
\text { the ball is according } \\
\text { to the range of an } \\
\text { open arm. } \\
\text { Average: } 14.07 \text {, } \\
\text { Average of the head } \\
\text { circumference } \\
: 49,04 \text { and the } \\
\text { average of body } \\
\text { mass index }=2.0\end{array}$ \\
\hline $\begin{array}{l}\text { c.the weight of a } \\
\text { basketball no. } 5\end{array}$ & gram & $\begin{array}{l}\text { between 350- } \\
410\end{array}$ & $\begin{array}{l}\text { The ideal weight } \\
\text { which is the safest } \\
\text { towards the impact } \\
\text { of bounces is } \\
\text { searched with the } \\
\text { average at } 49.04\end{array}$ \\
\hline Bouncing ability & $\mathrm{cm}$ & $\begin{array}{l}\text { Between } 120- \\
140, \\
\text { For physical } \\
\text { education } \\
\text { between } 80-110\end{array}$ & $\begin{array}{l}\text { When the ball is } \\
\text { bounced at the } \\
\text { height of } 180 \mathrm{~cm} \text {, } \\
\text { the bounce will be } \\
\text { between } 80-110 \\
\mathrm{~cm} \text {, with the height } \\
\text { average at } 150.28 \\
\text { and that of the limb } \\
\text { length at } 75.42\end{array}$ \\
\hline $\begin{array}{l}\text { The width of the } \\
\text { hem/ the border line } \\
\text { among panels }\end{array}$ & $\mathrm{cm}$ & $\leq 0.60$ & The line is black \\
\hline The abrasion strengh & & $\begin{array}{l}\leq 50 . \\
\text { The } \\
\text { performance is } \\
\text { not changed } \\
\text { after normal use }\end{array}$ & $\begin{array}{l}\text { The ball is saved } \\
\text { cleanly in a dry } \\
\text { room with a certain } \\
\text { humidity and } \\
\text { temperature. }\end{array}$ \\
\hline
\end{tabular}

Theoretically, designing a prototype learning equipment or media needs a long time for repetitive trials, revisions, and adjustment to the needs [22-24]. It is important to have modified equipment so that physical education runs smoothly [25].

\section{CONCLUSION}

Physical education equipment is closely related to its users so that designing a modified equipment needs certain criteria. Some of the important criteria are their functions, performance, safety, and easy modification for the development of physiology, sociology, and psychology of the users. 


\section{REFERENCES}

[1] M.A. Chase, M.E. Ewing, C.D. Lirgg and T.R. George, "The effects of equipment modification on children's self-i and basketball shooting performance," Research Quarterly for Exercise and Sport, vol. 65, no. 2, pp. 159-168, 1994.

[2] T.L. Pellett, H.A. Henschel-Pellett and J.M. Harrison, "Influence of ball weight on junior high school girls' volleyball performance," Perceptual and motor skills, vol. 78, pp. 1379-1384, 1994.

[3] R. Prodan and E.F. Grosu, "Specific Skills Development Using Appropriate Tools in the Tennis Game," Gymnasium, vol. 18, pp. 43-54, 2017.

[4] T.F. Gulhane, "Need for Advanced Facilities and Equipment in Physical Education Colleges," Journal of Sport and Physical Education, vol. 1, pp. 48-49, 2014

[5] A. Chapanis, "Ergonomics in product development: a personal view," Ergonomics, vol. 38, pp. 1625-1638, 1995.

[6] S. Giriwijoyo, Ilmu faal Olahraga. Bandung: PT. Rosda Karya, 2015.

[7] T. Reilly, "Ergonomics in sport and physical activity," Human Kinetics, 2009.

[8] T. Reilly, "Ergonomics in sport: an overview," Applied ergonomics, vol. 15 , pp. 243-244, 1984.

[9] R.A. Schmidt and C.A. Wrisberg, "Motor learning and performance: A situation-based learning approach," Human kinetics, 2008.

[10] R. Tinning, Becoming a Physical Education Teacher. Australia: Pearson Education, 2001.

[11] I.A. Harun and Djaenudin, Media Pembelajaran. Bandung: UPI, 2003.

[12] D.L. Galahue, Developmental Physical Education for Today's Children. USA: Brown \& Benchmark, 1996.

[13] T.R. Thomas and Lee, Ergonomics in Workplace. s.l.: www,hse.ie, 2010 .
[14] O. Wijoyo, Penggunaan Bola Modifikasi Dan Bola Standar Terhadap Kesan Subjektif Siswa Pada Pembelajaran Bolavoli. Bandung: Universitas Pendidikan Indonesia, 2015.

[15] Y.S. Rasip, Pengaruh Penggunaan Bola Modifikasi Terhadap Jumlah Waktu Aktif Belajar Dalam Pembelajaran Permainan Bola Voli. Bandung: Universitas Pendidikan Indonesia, 2015.

[16] J. Novakovich, S. Miah and S. Shaw, "Designing curriculum to shape professional social media skills and identity in virtual communities of practice," Computers \& Education, vol. 104, pp. 65-90, 2017.

[17] T. Amiel and T.C. Reeves, "Design-based research and educational technology: Rethinking technology and the research agenda," Journal of educational technology \& society, vol. 11, pp. 29-40, 2008

[18] J. Pool and D. Laubscher, "Design-based research: is this a suitable methodology for short-term projects?" Educational Media International vol. 53, pp. 42-52, 2016

[19] E. Nugraha, H. Firmansyah, S. Mujianto and D. Budiana, "Physica Education Learning Media Based on Antropometrcis Mapping for SMP Students in West Java," IOP Conference Series: Materials Science and Engineering, vol. 180, No. 1, pp. 012197, 2017.

[20] A. Méndez-Giménez, "Self-made materials in physical education contexts: an innovative complement to instructional models," 7th International Scientific Conference On Kinesiology, p. 240, 2014

[21] A.C. Bucher and L.M. Krotec, Mangemen of Physical Education and Sport. New York: Mac Graw Hill, 2002.

[22] D. Walker, Toward Productive design studies. London: Routledge, 2006

[23] H. Burkhardt, "From design research to large scale impact," Educational design research, 121-150, 2006.

[24] T. Anderson and J. Shattuck, "Design-based research: A decade of progress in education research?" Educational researcher, vol. 41, pp. 1625, 2012).

[25] National Children Hospital, "New national study finds increas in Physical education class-related injuries," 2009. [Online] Retrieved from: www.sciendaily.com, 2009/08/090803083640. 